\title{
SOBRE A FABRICAÇÃO CONTEXTUAL DE PESSOAS E COISAS: AS TÉCNICAS JURÍDICAS E O ESTATUTO DO SER HUMANO APÓS A MORTE*
}

\author{
Ciméa Barbato Bevilaqua
}

A reflexão sobre como o direito elabora a categoria de pessoa, em diferentes universos sociais, não é nova na antropologia. O privilégio analítico costumeiramente conferido às modalidades de construção da pessoa, porém, tende a reafirmar implicitamente o fundamento por excelência dos sistemas jurídicos ocidentais: uma fronteira naturalizada e, portanto, assumida como não problemática, entre pessoas e coisas. Uma melhor compreensão das maneiras pelas quais o direito constitui o mundo ao qual suas disposições se aplicam - em particular no que diz respeito às técnicas jurídicas de personificação (e de reificação) — parece exigir, ao contrário, que essa divisão não seja assumida como uma premissa, cuja consequência imediata é restringir a análise à busca de expressões particulares de uma distinção cuja existência e implicações não são questionadas (cf. Pottage 2004).

Com esse ponto de partida, meu objetivo é refletir sobre algumas formas de constituição e distinção de pessoas e coisas quando se trata de considerar juridicamente o ser humano após a morte, tendo como referência julgamentos de tribunais estaduais brasileiros. As decisões analisadas evidenciam que, no âmbito dos processos judiciais, pessoas e coisas não são categorias estáveis ou mutuamente excludentes. A categorização de um ente como pessoa ou coisa depende de uma distinção contingente operada no exame de situações particulares, tanto à luz da legislação quanto de valores oriundos da experiência social dos julgadores e sedimentados sob a forma de técnica especializada na doutrina e na jurisprudência. Se a integridade do organismo humano vivo, cujas fronteiras parecem autoevidentes, pode sustentar a assimilação simbólica entre o corpo individual e a pessoa como sujeito (Strathern 2005:116), a morte torna tal equação ambígua e favorece a emergência de outros arranjos. A disjunção entre corpo e agência permite, como se verá, que as técnicas jurídicas estabeleçam diferentes graus de reificação do cadáver e/ou de suas partes, assim como a fabricação de 
pessoas pela articulação de atributos de entes distintos, animados e inanimados. Essas variações conduzem a reconhecer que "o direito literalmente faz a diferença", isto é, que "as técnicas de personificação e reificação são constitutivas, mais que declaratórias, da ontologia na qual se baseiam" (Pottage 2004:5 e 9).

O papel da técnica jurídica na fabricação de pessoas e coisas tem sido analisado em particular no que diz respeito às repercussões normativas do desenvolvimento da biotecnologia (e vice-versa). Diversos trabalhos recentes, sob diferentes enfoques analíticos, tratam de processos de personificação e reificação associados ao transplante de órgãos e tecidos, às novas técnicas de reprodução assistida e ao patenteamento de material genético, entre outros desdobramentos da pesquisa científica (ver, p.ex., Pottage \& Mundy 2004; Strathern 2005; Pottage 2007). É preciso assinalar, contudo, uma diferença significativa entre as controvérsias jurídicas suscitadas pela definição do estatuto de objetos e relações associados ao desenvolvimento da biotecnologia, de um lado e, de outro, as decisões judiciais que sustentam a reflexão proposta neste artigo. No primeiro caso, trata-se da normatização de realidades emergentes cuja configuração é reconhecida pelos agentes como indissociável de sua representação jurídica. Já os protagonistas dos julgamentos examinados a seguir, embora também firmemente engajados em processos de fabricação ontológica, referem sua atividade a uma tradição (jurídica) e tendem a representá-la como a procura da correspondência adequada entre o universo das categorias jurídicas e os atributos essenciais de um mundo concebido como preexistente a elas.

Foram consultados 22 acórdãos, ${ }^{1}$ dos quais 11 do Tribunal de Justiça de São Paulo, oito do Tribunal de Justiça do Rio de Janeiro e os três restantes provenientes dos tribunais do Rio Grande do Sul, Minas Gerais e Maranhão. A análise desses julgamentos — que, conforme a classificação própria ao universo jurídico, compreendem questões de natureza privada e pública, civil e criminal, bem como suas sub-divisões - privilegia dois aspectos: a) a maneira como são construídos formalmente o objeto da disputa, os argumentos das partes e a decisão final; e b) de que modo tais técnicas jurídicas constituem e diferenciam pessoas e coisas. ${ }^{2}$

Considero inicialmente casos referentes à exumação indevida de restos mortais pela administração do cemitério onde se encontravam sepultados, seguida de sua perda ou remoção para a chamada sepultura (ou ossário) geral. Trato em seguida de casos caracterizados como crimes de vilipêndio e subtração de cadáver. Finalmente examino — de forma preliminar e tentativa, uma vez que tive acesso a somente um julgamento dessa natureza a questão do reconhecimento de direitos da personalidade post mortem. 
A título de exemplo do primeiro tipo de situação, descrevo de modo mais detalhado um julgamento da $1^{\text {a }}$ Câmara de Direito Público do Tribunal de Justiça de São Paulo, ocorrido em janeiro de 2007. ${ }^{3}$ Trata-se de ação de indenização por danos materiais e morais decorrentes da exumação e perda dos restos mortais da mãe do autor pela prefeitura municipal de Presidente Prudente, sem prévia informação ou consentimento. A sentença de primeiro grau julgou a ação procedente (em relação ao dano moral, sobre o dano material nada mais é dito) e condenou o município a pagar uma indenização de R\$3.600. O município apelou alegando que fez publicar em jornal local um edital de convocação para o recadastramento da sepultura, sem que o interessado se manifestasse. Considerando o jazigo abandonado, procedeu à exumação dos restos mortais. O julgamento de segundo grau, baseado num parecer de apenas três páginas do desembargador relator, confirmou a primeira decisão.

O que importa inicialmente é saber como, isto é, por meio de que operações, esse resultado é produzido. O primeiro passo do percurso que conduz à decisão sobre a demanda da prefeitura — tal como registrado no acórdão em questão - é a avaliação do seu procedimento no âmbito do próprio processo. Até certo ponto, não vem ao caso o que a municipalidade efetivamente fez ou deixou de fazer, mas que "não comprovou" nos autos o cumprimento do "devido processo legal" para efetuar o apossamento administrativo da sepultura, nem a publicação de edital.

O caráter circunscrito e autorreferenciado dos processos judiciais tem sido apontado por diferentes autores. ${ }^{4}$ Para a atual reflexão, porém, é o segundo passo do raciocínio desenvolvido pelo relator que oferece maior interesse. Ao se estabelecer, no e pelo processo, que a prefeitura não notificou adequadamente o interessado (quando, por dever legal, deveria tê-lo feito), afasta-se a consideração de um possível abandono da sepultura por parte de seu responsável e, assim, o argumento tácito da municipalidade, segundo o qual o descaso demonstrado pelo túmulo da mãe não justificaria a reivindicação de ressarcimento por danos morais. O dano moral pode surgir, desta forma, como autoevidente: é suficiente declará-lo para que ele exista. É este o passo conclusivo do voto em questão, do qual reproduzo um trecho:

O dano moral decorre in re ipsa, sendo inescondível a afetação prejudicial no patrimônio moral do autor com a exumação não autorizada e o lançamento dos despojos mortais da genitora do demandante a lugar desconhecido [...] (TJSP, Acórdão $\mathrm{n}^{\circ}$ 01203172/2007). 
A expressão latina in re ipsa, que confere legitimidade ao enunciado pela invocação implícita de uma tradição jurídica reconhecida (e reivindicada) pelo direito brasileiro, ${ }^{5}$ exprime a ideia de que determinado resultado é consequência necessária e inevitável de certa conduta, o que permite dispensar sua comprovação em juízo. No julgamento em questão, a presunção de que o dano moral decorre imediatamente da ação da prefeitura é também sustentada pela jurisprudência. O relator reproduz as ementas de quatro decisões dos tribunais de justiça de São Paulo e do Rio de Janeiro, relativas a casos similares, todas concedendo indenização por dano moral a parentes de pessoas sepultadas em cemitérios públicos cujos restos mortais foram extraviados. Somente uma delas faz referência a um fundamento legal, ${ }^{6}$ que não chega a ser mencionado ou discutido pelo relator do caso ora examinado. As decisões incorporadas ao parecer valem por si mesmas, isto é, sua própria qualidade de julgamentos anteriores àquela decisão as torna incontroversas, assim como a decisão atual poderá vir a sustentar futuros julgamentos.

Situações como a descrita acima, de exumação não autorizada e perda dos restos mortais, ou de remoção indevida para a sepultura ou ossário geral do cemitério, parecem ser corriqueiras, a avaliar pelo número de processos dessa natureza que chegam, já em grau de recurso, aos diferentes tribunais estaduais. Quaisquer que sejam as circunstâncias específicas, as decisões conduzem costumeiramente à indenização do autor por danos morais.

Em diversos casos, a parte contrária (em regra a municipalidade, responsável pelo cemitério) questiona, em sua defesa, o interesse e o zelo do autor da ação pela conservação do túmulo, isto é, coloca em dúvida a autenticidade do sofrimento moral experimentado pelo demandante em razão do extravio dos restos mortais de um parente cujo túmulo não recebia nenhum cuidado. Essa linha de argumentação é sistematicamente afastada pelos julgadores nos acórdãos examinados. O vínculo entre os restos mortais de um parente próximo e a integridade moral do familiar que propõe a ação não requer, para se configurar, nenhuma conduta específica deste que demonstre concretamente preocupação com o morto. Assume-se sua existência, que prescinde de atualização ou verificação.

A premissa implícita nesses julgamentos parece ser o vínculo naturalizado - e, portanto, necessário - entre o que proponho denominar a "materialidade" dos restos mortais de um parente próximo e a "interioridade" 
do familiar que propõe a ação, aqui entendida como sua constituição íntima (reconhecida no âmbito processual como singular) como ser moral, dotado de autoconsciência e intencionalidade e, por isso mesmo, suscetível aos efeitos das ações de outrem. É isto o que permite que a existência do dano moral seja considerada autoevidente em todas as decisões. Dito de outro modo, em situações como a descrita acima, a técnica jurídica constrói uma modalidade específica de pessoa pela dissociação e (re)articulação dos planos da "materialidade" e da "interioridade" de entes distintos. O parente vê acolhido seu pedido de indenização ao ser constituído e reconhecido em sua "interioridade" moral, que se define, na circunstância em questão, a partir da "materialidade" do parente morto, absorvida como parte de sua própria substância moral - na expressão jurídica, de seu "patrimônio subjetivo". Entende-se assim por que não se requer nenhuma expressão concreta da ligação afetiva entre o autor da ação e o parente morto para se admitir o dano e a indenização: o sofrimento moral é decorrência imediata dessa forma específica de fabricação da pessoa.

Consequentemente, não é fortuito que, tanto nos casos de perda de restos mortais, quanto nos de remoção indevida para uma sepultura coletiva, um dos elementos decisivos do julgamento favorável ao autor da ação seja a impossibilidade de identificação que daí resulta, isto é, de particularização dos restos mortais, que agora se confundem com os de terceiros num ossário geral. Desfaz-se assim a conjunção inequívoca entre a interioridade da pessoa viva e os despojos do parente morto, absorvidos como parte do patrimônio moral daquela. Mas se a condição de pessoa é irremediavelmente afetada pela impossibilidade de individualização dos restos mortais, ${ }^{7}$ o conjunto indiferenciado de despojos depositados numa sepultura geral continua a reter uma qualidade genericamente humana, de modo que o dano verificado se restringe ao autor da ação.

Em alguns dos julgamentos examinados, contudo, a excepcionalidade das circunstâncias referidas nos autos parece ameaçar a própria fronteira ontológica entre o humano e o não humano, tal como concebida pelos julgadores. Nesses casos, os acórdãos evidenciam um movimento específico da técnica jurídica - que antecede e fundamenta o exame das demandas das partes — no sentido de recompor cuidadosamente tais limites. Exemplo disso é um julgamento do Tribunal de Justiça do Rio de Janeiro, ocorrido em fevereiro de $2008{ }^{8}{ }^{8}$ cuja origem se encontra na exumação dos restos mortais do pai da autora pela administração do cemitério de Inhaúma. Confundidos com os de terceiros, os despojos não têm por destino, como nas situações discutidas acima, uma sepultura geral: em condições inexplicadas, acabam sendo removidos para o aterro sanitário do município de Duque de Caxias. 
Convertidos em lixo, esses restos mortais não são apenas desindividualizados: o conjunto é simultaneamente esvaziado de qualquer qualidade humana distinguível, (con)fundindo-se num amálgama indiferenciado de matéria inerte..$^{9} \mathrm{O}$ que é percebido no processo como um escândalo (fático e lógico), porém, não é a possível transformação de pessoas em coisas — sob esse aspecto, seria pertinente inclusive indagar se os resíduos (humanamente) indesejáveis que compõem o lixo retêm a própria condição de coisas, na medida em que esta supõe a existência de unidades que, justamente por serem distinguíveis de outras, possibilitam o exercício de direitos específicos, notadamente o de propriedade. Ao enfatizar que o aterro sanitário é o "local onde, normalmente, os animais domésticos procuram por alimento", a sentença do juiz de primeira instância deixa claro o potencial profundamente perturbador da iminente conversão de restos mortais humanos em substância viva não humana.

Da mesma forma, o desembargador responsável pelo exame do recurso apresentado pela prefeitura se ocupa demoradamente não do exame dos fatos do processo e do dano moral sofrido pela autora - tido como incontroverso pelos julgadores - mas do restabelecimento de uma fronteira ontológica que parece gravemente ameaçada pela incúria da administração do cemitério. ${ }^{10}$ Por meio do emprego de uma técnica jurídica peculiar, cujo fundamento não é a legislação positiva, mas um deslizamento sutil entre tempo mítico e cronologia histórica, o argumento desenvolvido no parecer erige uma natureza humana tão singular quanto imutável. Com o propósito de caracterizar a continuidade essencial do cuidado, tido como especificamente humano, com os mortos, o parecer busca o exemplo remoto das "pirâmides monumentais" erigidas pelos egípcios para "preservar os restos mortais de seus entes queridos". Enumera em seguida diferentes passagens do Antigo Testamento - isto é, eventos não apenas anteriores ao nosso cômputo da história, mas situados na dimensão atemporal do mito - para concluir que "sepultar com dignidade os seus mortos é algo inerente à natureza humana e direito que nos acompanha desde os tempos dos grandes patriarcas de Israel". Se a primeira parte da frase coloca o cuidado com os mortos como preocupação natural e tipicamente humana, a segunda retira dessa condição um direito essencial a ser reconhecido e protegido pelo direito positivo - e, com este passo, é possível regressar ao plano dos fatos do processo e reiterar a indenização concedida em primeira instância.

Mas se a existência do dano moral não é jamais questionada em processos relativos ao extravio de restos mortais, os julgadores tendem a avaliar a intensidade desse dano ao decidir sobre sua expressão pecuniária, isto é, sobre o valor da indenização. Ao lado da doutrina seguidamente invocada 
segundo a qual o montante da indenização deve ser suficiente para assegurar seu caráter punitivo, mas não a ponto de caracterizar vantagem excessiva àquele que a recebe, é possível identificar dois outros elementos que entram em consideração nos casos analisados: a contiguidade entre a pessoa que requer a indenização e o morto, avaliada em termos do grau de parentesco; e o intervalo temporal entre o dano e a demanda de ressarcimento. ${ }^{11} \mathrm{~A}$ título de ilustração, menciono brevemente dois outros julgamentos do TJERJ.

No primeiro deles, ${ }^{12}$ o relator questiona o fato de a ação ter sido proposta pela mãe e a irmã do morto, e não por sua esposa e filhos. O fato - ou melhor, uma valorização diferencial das relações de parentesco que, sem previsão legal específica, parece privilegiar os laços constituídos voluntariamente em detrimento das conexões dadas pela consanguinidade — leva-o a pôr em dúvida a boa fé das autoras, que teriam "ingressado no presente feito com vistas, ao meu sentir, [a] se locupletarem às custas do que se pode dizer uma falha humana, e que esta falha não tenha sido observada pelas autoras quando do traslado dos restos mortais do filho e irmão, que foi enterrado em jazigo geminado".

Já no segundo julgamento, ${ }^{13}$ o tribunal reduz o valor da indenização concedida pelo juízo de primeiro grau sob o argumento de que, tendo se passado cerca de dezoito meses entre a ocorrência do dano e a instauração da ação indenizatória, "a dor moral suportada, por evidente, já restava mitigada" [ênfase original] — o que traduz a premissa de que o vínculo entre os vivos e os mortos, ainda que jamais se desfaça inteiramente, tende a se afrouxar com o tempo, talvez à medida do declínio da própria materialidade do cadáver.

Esse último caso também oferece outros elementos merecedores de um exame mais cuidadoso, que permitem identificar uma modalidade distinta de construção de pessoas e coisas pelas técnicas jurídicas. Os fatos que motivaram o processo não diferem em suas linhas gerais daqueles que figuram nos acórdãos referidos até o momento. O ex-cônjuge ${ }^{14}$ da autora da ação foi sepultado no Cemitério São João Batista, no Rio de Janeiro, administrado pela Santa Casa de Misericórdia. Por ocasião do sepultamento, não foi fornecida a cópia do contrato nem qualquer informação sobre sua vigência e sobre os demais procedimentos adotados pela administração do cemitério. Algum tempo depois, ao visitar a sepultura e encontrá-la violada, a autora da ação soube que o corpo havia sido exumado e cremado, junto com outros, em virtude do término do prazo de três anos de arrendamento do túmulo. Tal como nos demais casos, a indenização por danos morais é concedida em primeira instância e a parte contrária apela ao juízo de segundo grau.

O mecanismo formal subjacente à argumentação do desembargador que analisa o recurso não oferece novidade: trata-se de examinar os fatos e 
as alegações das partes, tal como constituídos no âmbito do processo, e de qualificá-los à luz da legislação (assim como de interpretações anteriores dos textos legais que, em regra, incorporam elementos de outros domínios), procedimento que possibilita e sustenta a decisão final. Expostos os acontecimentos, refuta-se de imediato a primeira alegação da Santa Casa de Misericórdia, a saber: não teria ficado "demonstrad[a] nos autos a consternação suportada pela autora, [que] teria contribuído para os fatos, agindo com descaso e inércia". Conforme se verifica nos casos anteriores, o voto do relator assume que "o dano [moral] ocorre in re ipsa". O exame da segunda alegação apresentada - a estrita observância da legislação pertinente pela administração do cemitério - é que comporta um desvio significativo, embora o procedimento formal seja similar ao que sustenta o primeiro passo. Diferentemente dos casos relativos a cemitérios públicos, neste e em outros acórdãos do Tribunal de Justiça do Rio de Janeiro envolvendo concessionários privados de serviços funerários, a qualificação dos fatos é feita com base no Código de Defesa do Consumidor. ${ }^{15}$

Assim, mesmo que não se desconsidere o sofrimento dos autores dessas ações em virtude do destino dado aos restos mortais de uma pessoa próxima, o dano moral é caracterizado - também ou sobretudo - pela má prestação de um serviço, independentemente de sua natureza específica. ${ }^{16}$ Desse modo, a aplicação de uma técnica jurídica muito geral - a determinação e posterior categorização dos fatos no âmbito do processo - faz com que o foco deslize sutilmente do vínculo entre parentes para o vínculo contratual entre aquele que arrendou a sepultura por tempo determinado e a administradora do cemitério, responsável pela prestação do serviço. Tal como nas situações já examinadas, também aqui o acento incide sobre a pessoa do autor da ação: a diferença reside no modo como ela emerge da aplicação da técnica jurídica. Nos casos anteriores, a pessoa era construída como uma relação entre atributos de entes distintos - a interioridade moral do demandante e a materialidade dos restos mortais de seu parente. Já nos casos em que os fatos do processo são qualificados com base no Código do Consumidor, a pessoa, definida a partir da relação contratual com um terceiro, caracteriza-se pela indissociabilidade entre atributos que lhe são privativos, situados em dois planos complementares: sua interioridade subjetiva e sua capacidade material de agir no mundo exterior. Desse modo, considera-se que a integridade moral da pessoa, sua dimensão mais interna e particular, é atingida a partir de uma expressão concreta de sua agência no mundo - o contrato. Mais especificamente, o dano decorre da desconsideração de sua dignidade por parte do parceiro contratual que descumpriu sua obrigação. Nem o dano nem a obrigação desatendida guardam qualquer particularidade 
ligada à natureza do serviço ou à relação entre vivos e mortos. A conduta da administração do cemitério é caracterizada como descumprimento do dever legal de informar, que impõe ao fornecedor a obrigação de indenizar. ${ }^{17}$

Embora os processos mais frequentes envolvendo mortos sejam aqueles referentes à conduta imprópria da administração do cemitério, público ou privado, certo número deles diz respeito a violações de sepulturas perpetradas por terceiros ou outras condutas que ensejam processos criminais. O Código Penal brasileiro data de 1940 e contém, como parte de um amplo sistema de classificação de tipos de condutas consideradas criminosas, um capítulo específico sobre os "crimes contra o respeito aos mortos". A despeito das inúmeras emendas feitas ao código em seus setenta anos de vigência, este capítulo permanece com sua formulação original. Note-se que a proteção da lei se dirige a um bem imaterial e coletivo, o "respeito" que se supõe que os vivos tenham pelos mortos, e não diretamente aos mortos, considerados de modo independente de sua relação com os vivos. O código prevê quatro tipos de crimes: o impedimento ou perturbação de cerimônia funerária (art. 209); a violação de sepultura (art. 210); a destruição, subtração ou ocultação de cadáver (art. 211) e o crime de vilipêndio a cadáver ou suas cinzas (art. 212).

Uma vez que a definição desses crimes é sumária - a lei se limita a enunciar cada tipo e a estabelecer a pena correspondente ${ }^{18}$ — os julgamentos se apoiam fortemente nas considerações de doutrinadores e, por meio destes, em uma série de operações de categorização cujos princípios são exteriores ao texto da lei. ${ }^{19} \mathrm{Na}$ tipificação legal, embora o bem tutelado seja imaterial e coletivo (o "respeito aos mortos"), o crime é perpetrado e reconhecido por meio de uma ação sobre a materialidade de restos mortais individualizados. Conforme os acórdãos examinados referentes ao crime de vilipêndio a cadáver, porém, o ato por si só, ainda que reconhecido como violento — por exemplo, o esquartejamento do corpo post mortem - é insuficiente para ensejar sua classificação no tipo penal correspondente. A argumentação desenvolvida pelos operadores jurídicos se dirige a perscrutar a intenção subjetiva do agente, o fim visado no momento da ação. Ao se concentrar no agente, e no vínculo entre sua ação no mundo e seu estado interior, a técnica jurídica produz, de um lado, uma pessoa constituída pela indissociabilidade entre "interior" e "exterior" (intencionalidade e agência no mundo), tal como nos exemplos imediatamente acima; mas também, de outro, e por implicação, 
constitui como coisa o cadáver, que apenas suporta a ação de outrem. Este movimento é perceptível sobretudo nos casos em que não fica estabelecida no processo a intenção específica do réu de ofender ou desrespeitar.

A condição de coisa, no entanto, comporta gradações, a depender do contexto e do modo de qualificação de fatos particulares. Ofereço como primeiro exemplo um julgamento do Tribunal de Justiça do Rio Grande do Sul. ${ }^{20}$ Sumariamente, a situação, ocorrida no município de Santa Cruz do Sul, é a seguinte: um pedreiro de 34 anos mata seu vizinho a golpes de porrete na calçada em frente às residências de ambos. Coloca o corpo no porta-malas do carro e o transporta até o sítio de seus pais, na zona rural do município. Lá, com a ajuda do irmão mais velho, o cadáver é disposto em uma cova e queimado com gasolina. O local é coberto com terra e palha.

O primeiro irmão foi preso e pronunciado por homicídio qualificado. Além disso, ambos foram considerados incursos nos crimes dos artigos 211 e 212 do Código Penal, a saber: destruir, subtrair ou ocultar cadáver ou parte dele; e vilipendiar cadáver ou suas cinzas. O recurso da defesa, objeto do julgamento a que me refiro, pretendia a não caracterização do crime de vilipêndio a cadáver. Interessa examinar aqui o modo como o desembargador relator examina e qualifica os fatos, dando razão à defesa.

Considerando que o Código Penal se limita a enunciar os crimes contra o "respeito aos mortos", torna-se necessário, antes de qualquer outro passo, definir o campo semântico compreendido pela expressão "vilipêndio a cadáver". Para isso o julgador busca o apoio da doutrina, isto é, baseia-se na interpretação de comentadores reputados. O voto recorre a obras de três doutrinadores. Nos trechos citados, verifica-se o mesmo movimento de categorização. O primeiro passo é estabelecer o significado geral da ação de vilipendiar, o que é feito pela justaposição do primeiro verbo a outros, cujo significado se afigura implicitamente mais bem conhecido ou menos disputável: vilipendiar significa "aviltar, ultrajar, tratar com desprezo". Esse elenco de sinônimos, no entanto, ainda se situa num plano genérico e impreciso: a interpretação é circular, insuficiente para o exame de casos concretos.

O passo seguinte, portanto, é definir as espécies de atos correspondentes ao gênero. Tem-se então que a ação de vilipendiar "pode ser praticada mediante palavras, escritos ou gestos". Mas ainda é preciso ir além: que conteúdo específico se requer dessas diferentes formas de expressão para que se caracterize o crime? O julgador apresenta então uma lista de atos que, mais que exemplificar, constituem a própria categoria da qual são exemplos: “tirar as vestes do cadáver, escarrar sobre ele, cortar algum membro (com o fim de escárnio), atos de necrofilia, o emprego de vocábulo ultrajante, o gesticular ofensivo, o arremesso de imundícies" [ênfase original]. 
Os diferentes doutrinadores citados reproduzem, quase literalmente, as mesmas expressões, de modo que é sobretudo pela repetição que uma percepção difusa fundada no senso comum se cristaliza como exegese técnica passível de ser invocada com autoridade no julgamento de uma conduta particular. Desse modo, no caso aqui referido, o desembargador relator pôde concluir que a "prova dos autos não registra nenhum ultraje, nenhum aviltamento ao cadáver da vítima e a denúncia sequer indica nenhuma circunstância nesse sentido". O recurso da defesa é bem-sucedido.

O exame de outro caso, este julgado pelo Tribunal de Justiça do Maranhão, ${ }^{21}$ permite ir um pouco além. No plano fático, nada aproxima as duas situações: se o primeiro caso envolvia um homicídio, este diz respeito ao sócio-gerente de um cemitério que procedeu à exumação de restos mortais em virtude da falta de pagamento das prestações referentes ao arrendamento dos túmulos. Para a reflexão que nos ocupa, não é necessário apresentar os demais detalhes do processo. É suficiente verificar que também aqui a desembargadora responsável pelo exame do caso recorre à doutrina para decidir em favor do réu. Reproduzo um trecho do seu voto que traduz de forma mais clara a importância conferida à disposição subjetiva do autor cuja determinação, evidentemente, só pode ser conjectural e especulativa para configurar os crimes contra o "respeito aos mortos".

[O] procedimento efetivado pelo paciente deixa claro que sua volição em exumar os restos mortais, em caso de inadimplência, teve por mote fazer valer as cláusulas contratuais, e não ofender o sentimento de piedade com os mortos, o que viria a caracterizar o ilícito do artigo 210 do Código Penal [violação de sepultura], que somente se tipifica quando o agente integra em sua conduta o elemento subjetivo do tipo, o dolo, ou seja, a vontade deliberada e consciente de violar ou profanar sepulturas ou restos mortais (TJMA, Habeas Corpus 16318/2000).

Considerando a importância assumida pela voz dos doutrinadores nos dois casos mencionados, assim como a natureza de suas considerações, talvez seja possível sugerir que a exegese dos artigos do Código Penal que tratam dos crimes contra o "respeito aos mortos" permite - e talvez mesmo exija, considerando-se que o bem juridicamente protegido é um valor imaterial, e que os tipos penais que exprimem sua violação são enunciados de modo genérico e impreciso - a introdução de parâmetros classificatórios exteriores ao universo jurídico, oriundos do próprio comentador e de sua experiência social. É assim que o desrespeito e o ultraje são concebidos na doutrina jurídica - e, por conseguinte, na jurisprudência - unicamente como resultado de uma disposição subjetiva consciente: uma ofensa fortuita não é ofensa. 
Quais são os efeitos desse movimento no que se refere a processos de personificação e reificação? Vê-se que o foco se concentra inteiramente no polo do agente do crime: trata-se de estabelecer a posteriori suas intenções antes e durante a ação (um passo concebido como não problemático no âmbito processual), o que significa que a técnica jurídica constitui o réu como pessoa dotada de uma intencionalidade que se manifesta concretamente em sua agência no mundo. Mas o acento recai decididamente no plano interior: é a vontade que, antes e sobretudo, define a pessoa. Correlativamente, reifica-se o objeto da ação, isto é, o cadáver desprovido de vontade e agência. Admite-se nos processos que se trata de coisa de natureza especial, mas o percurso construído pelos julgadores aponta que o valor suportado pelo cadáver é uma questão a ser decidida entre os vivos: uma ação sobre o cadáver não é suficiente para caracterizar o crime de desrespeito aos mortos. Para tal caracterização, a técnica jurídica pretende colocar em perspectiva o plano interno e subjetivo da intencionalidade do autor e disposições igualmente internas da coletividade (o sentimento de respeito aos mortos), objetivadas no Código Penal. Desse modo, acentua-se a descontinuidade entre vivos e mortos, com base numa distribuição de qualidades exclusivas: cada polo se define pela ausência ou esmaecimento do atributo crucial para a constituição do polo contrário.

Entretanto, a fronteira ontológica traçada pela técnica jurídica entre pessoas e coisas não é estável, nem coincide necessariamente com a distinção entre vivos e mortos. Conforme o contexto, o morto pode ser considerado ainda mais acentuadamente coisa. Ou, de modo inverso, a atribuição ao ser humano de uma interioridade que subsiste após a morte pode desfazer radicalmente a fronteira entre vivos e mortos e, ao mesmo tempo, redefinir a distinção entre pessoas e coisas com base em outros atributos.

O aprofundamento da constituição do ser humano morto como coisa se evidencia em processos que tratam da violação de sepulturas e da remoção de partes do cadáver — próteses dentárias de ouro, notadamente - para posterior comercialização. Nos dois acórdãos dessa natureza a que tive acesso na íntegra, ambos do Tribunal de Justiça de São Paulo, ${ }^{22}$ os réus foram inicialmente acusados pelos crimes de violação de sepultura e furto (respectivamente, artigos 210 e 155 do Código Penal). Nos dois casos, são bem-sucedidos os apelos da defesa para descaracterizar o crime de furto, cuja pena varia entre dois e oito anos de reclusão. O debate jurídico sobre a 
classificação adequada dos fatos define simultaneamente o estatuto ontológico do cadáver. Em ambos os recursos, a decisão depende de dois passos: a definição preliminar do que constitui furto e, em seguida, o cotejo entre tal definição e os elementos do processo.

À luz do Código Penal, a definição de furto não parece oferecer dificuldade: o furto é crime patrimonial, o que pressupõe que haja lesão do patrimônio de uma pessoa, física ou jurídica, para configurá-lo. Mas se a definição se afigura precisa, sua aplicação é controversa: pode o cadáver ser objeto de tal crime? A partir de uma vaga referência à tradição do direito romano, pelo emprego de expressões latinas consagradas no universo jurídico, os julgadores se apoiam na doutrina mais recente para estabelecer:

[O] cadáver não pode ser objeto material do furto, como regra geral, nem suas partes, por não constituir patrimônio, no sentido econômico, não ser coisa alheia. Não se pretenda dizer que ele pertence à família, que é coisa que faz parte do patrimônio dos herdeiros do morto e que estes seriam, de conseguinte, as vítimas do crime de furto. Seria risível pensar em tal hipótese. Se fosse assim, teria o cadáver que ser sempre objeto de inventário (TJSP, Apelação 53.500-3/1987 — Revista dos Tribunais 619/291).

Não entra em discussão portanto — na doutrina ou nos autos — a possibilidade de se caracterizar o furto de uma prótese dentária como um ato contra a própria pessoa do morto, cuja representação jurídica poderia ser assumida por um familiar. Esta hipótese implicaria não somente assimilar juridicamente corpos humanos inanimados e pessoas vivas, mas também enfrentar o difícil problema do reconhecimento de direitos de propriedade sobre partes do corpo humano, mesmo que se trate de direitos do sujeito sobre seu próprio corpo. Num movimento que evoca a noção de "fabrication by default" proposta por Strathern (2005:116), essas questões são deliberadamente evitadas ao se atribuir ao cadáver, de forma incontroversa nesse contexto, o estatuto de coisa. ${ }^{23}$ Mas se a técnica jurídica constitui o cadáver como coisa, confere-lhe também o estatuto de coisa de tipo especial: trata-se de res extra commercium, isto é, não se admite que possa ser propriedade de alguém e que possa ser introduzida no fluxo das trocas econômicas. Como consequência desse movimento, que habilmente continua a evitar as implicações mais espinhosas da conversão de pessoa em coisa, torna-se impossível que o cadáver venha a ser objeto de furto.

A afirmada extracomercialidade dos restos mortais humanos, porém, não é absoluta, mas situacional. Os próprios acórdãos se ocupam em distinguir as situações em análise daquelas em que um cadáver pode constituir 
legalmente o patrimônio de terceiros, caso em que se torna "coisa comum" e passível de furto. Segundo a doutrina citada pelos julgadores, isto ocorre, por exemplo, no caso de achados arqueológicos, ou quando um cadáver foi destinado a um museu ou instituto científico, para estudo ou exposição. Nessas condições, a subtração do cadáver ou de suas partes constitui crime patrimonial caracterizável como furto. Ou seja, a relação jurídica de propriedade equaliza as coisas passíveis de compor o patrimônio objetivo de alguém e, assim, retira do cadáver humano a especificidade que, em outras situações, continua a diferenciá-lo de outros objetos. Já nos casos acima referidos, o acionamento da noção de res extra commercium permite que a óbvia intenção dos réus de comercializar as coroas dentárias extraídas dos cadáveres seja tida como irrelevante para caracterizar o furto. Dito de outro modo, a partir da noção de propriedade a técnica jurídica estabelece diferentes graus de reificação da substância humana.

Inversamente, há situações nas quais o ser humano morto continua a ser concebido como dotado de interioridade, vontade e honra, ainda que a manifestação de sua vontade necessariamente anteceda a morte e que a defesa de sua honra e de sua memória deva ser concretamente assumida por terceiros. Diferentes acórdãos analisados contêm menções a desejos manifestados em vida pelo morto, um tema que não oferece maiores dificuldades do ponto de vista dos operadores do direito, uma vez que a codificação civil se ocupa detalhadamente de figuras como o testamento e outras disposições a serem cumpridas após a morte daquele que as manifesta, estabelecendo as condições para sua efetivação ou representação judicial. Importa notar apenas que o reconhecimento das disposições estabelecidas (em vida) pela pessoa morta é também o passo que conduz à extinção dessa personalidade agora desprovida de corpo. A vontade, como atributo constitutivo da pessoa, manifesta-se postumamente de modo imperativo, mas de uma só vez e de uma vez por todas.

Outras possibilidades se abrem, porém, a partir da reflexão sobre os chamados direitos da personalidade, entendidos como aqueles direitos inerentes à pessoa e à sua dignidade, estabelecidos no artigo $5^{\circ}$ da Constituição Federal e aos quais o Código Civil de 2002 consagra um capítulo próprio (artigos 11 a 21). A positivação dos direitos à honra, à imagem e à intimidade, dentre outros, coloca de imediato uma nova questão: a previsão legal se estende também aos mortos? É possível admitir que os mortos mantenham direitos 
da personalidade, tendo em vista que a legislação define tais direitos como irrenunciáveis e intransmissíveis ? $^{24}$

Numa primeira aproximação, o debate doutrinário recente sobre a questão dos direitos da personalidade post mortem permite distinguir (ao menos) duas posições gerais que, ao equacionar juridicamente a incapacidade do morto de se manifestar diretamente e requerer direitos, expressam diferentes modos de fabricação de pessoas e coisas. A primeira posição, possivelmente majoritária, sustenta que a personalidade cessa com a morte: mesmo que se pudesse reconhecer o contrário, os efeitos práticos deste reconhecimento seriam nulos em virtude da "extinção da capacidade jurídica" (Amaral 2000:221), isto é, da possibilidade efetiva de manifestação da vontade por parte do morto. Desta perspectiva, o estatuto de pessoa fundamenta-se na impossibilidade de dissociação entre interioridade (subjetiva) e agência (material). Desse modo, a personalidade jurídica só pode corresponder à pessoa humana viva, dotada de uma interioridade a ser protegida juridicamente, mas também da condição de exercer concretamente os direitos que emanam dessa interioridade. Em outros termos, entende-se que não há personalidade jurídica sem "capacidade jurídica"; existência biológica e existência jurídica não podem deixar de coincidir.

A segunda vertente sustenta que o artigo 12 do novo Código Civil, ${ }^{25}$ ao tratar da proteção aos direitos da personalidade, reconhece sua continuidade após a morte. A impossibilidade de uma pessoa morta requerer diretamente a proteção jurídica de seus direitos não é entendida como obstáculo, uma vez que o próprio texto legal define o cônjuge ou parentes próximos como representantes legítimos em juízo da pessoa morta. Ainda de acordo com essa exegese, também o artigo 20 do Código Civil, que concerne à proteção da imagem da pessoa, implicaria o reconhecimento dos direitos do morto (cf., p.ex., Tartuce 2005). Em termos mais gerais, entende-se que os entes que compõem o universo jurídico não dependem da, nem precisam corresponder à, projeção de algo exterior a esse universo - e é isto o que permite à técnica jurídica atingir o gradiente máximo da personificação. O reconhecimento da pessoa não apenas prescinde da materialidade do corpo, mas também de uma faculdade interior efetivamente capaz de se atualizar no mundo: é suficiente sua existência no âmbito do processo. ${ }^{26}$

Nesse movimento, a definição jurídica de coisa também é alterada. Segundo um entendimento que tem se consolidado entre os doutrinadores, a "criatividade humana" é definida como bem de caráter extrapatrimonial, cuja titularidade não pode ser transferida a outro sujeito - o contrário implicaria, como observa Strathern (2005:154), admitir direitos de propriedade sobre pessoas. Já a exteriorização da capacidade geradora do intelecto num invento 
ou obra de arte pode constituir de modo não problemático coisa material e patrimonial (cf. Gediel 2000). A partir dessa especificação efetuada pela técnica jurídica, a pessoa passa a conter - ou a se desdobrar - em elementos dotados de diferentes graus de alienabilidade. Os bens da personalidade compõem o núcleo inalienável da pessoa, não podendo ser dispostos nem pela vontade dela mesma. O âmago da pessoa é assim o limite, não só do mercado, mas também de sua própria vontade: inalienável e indisponível, distingue-se do desdobramento de suas próprias faculdades no mundo sob a forma de coisas com valor patrimonial, estas sim passíveis de figurar em fluxos econômicos e apropriáveis por outros sujeitos sem que ocorra uma diminuição da capacidade criadora que lhes deu origem.

O caminho percorrido neste texto indica que a técnica jurídica não opera, como às vezes se supõe, pelo estabelecimento da correspondência apropriada entre, de um lado, um conjunto de categorias normativas e, de outro, entes cujo estatuto ontológico é estável e independente das operações processuais. Ao contrário, os acórdãos analisados evidenciam a constituição contextual dos entes que povoam os processos como pessoas e/ou coisas, por meio de uma distribuição contingente de atributos diferenciais que ora postula uma identidade entre pessoa (sujeito de direito) e ser humano, ora se afasta de uma inspiração jusnaturalista e constitui pessoas e coisas sem afirmar uma correspondência necessária com qualidades tidas como inatas ou naturais. ${ }^{27}$

A coexistência dessas perspectivas diferenciadas conduz, em primeiro lugar, a reconhecer o direito como um poderoso operador ontológico que efetivamente constrói o mundo ao qual suas disposições se referem. Mas se este é um passo necessário para uma melhor compreensão de processos de personificação e reificação no universo jurídico, evidencia-se também a importância da consideração analítica da forte segmentação interna desse universo. Mesmo a análise de um conjunto restrito de decisões judiciais indica que é insuficiente falar da divisão entre pessoas e coisas efetuada pelo direito ocidental moderno, desconsiderando a complexa topografia dos ramos do direito e de suas expressões institucionais. Como observa Hermitte, cada uma dessas instâncias trabalha à sua maneira os objetos que apreende, não apenas sem buscar coerência com as demais mas, ao contrário, a partir de uma lógica de crescente autonomização cujas consequências compreendem, entre outras, a constituição de "objetos híbridos", categorias intermediárias entre coisas e pessoas (Hermitte 1998:18 e 24). 
Ciméa Barbato Bevilaqua é professora do Programa de Pós-Graduação em Antropologia Social da Universidade Federal do Paraná. E-mail: <cimea@ uol.com.br>

\section{Notas}

* Versões preliminares deste texto foram apresentadas no GT Antropologia do Estado, na 26 $6^{\text {a }}$ Reunião Brasileira de Antropologia (Porto Seguro, junho de 2008) e no seminário Antropologia do Estado: etnografia e teoria, realizado pelo Departamento de Antropologia da UFPR (Curitiba, novembro de 2008). Agradeço especialmente a Luiz Eduardo Abreu pelos comentários e sugestões nessas duas oportunidades. Agradeço também ao parecerista anônimo de Mana, cujas observações permitiram o aprimoramento da reflexão aqui proposta.

${ }^{1}$ Acórdão é a decisão judicial proferida em segundo grau de jurisdição pelos tribunais. Conforme dispõe o Código de Processo Civil (arts. 458 e 563), o acórdão é composto por quatro elementos essenciais: ementa, relatório, motivação (ou fundamentação) e dispositivo. A ementa é a síntese do acórdão, resumindo os aspectos do caso tidos como fundamentais. No relatório são descritos os fatos do processo e o direito que está sendo discutido pelas partes. A motivação ou fundamentação, que resulta da análise feita pelos juízes ou ministros sobre as questões de fato e de direito expostas no relatório, estabelece as bases para a decisão do órgão judicial. $\mathrm{O}$ dispositivo, parte final do acórdão, expõe o posicionamento retirado do relatório e da motivação, isto é, a decisão do tribunal.

${ }^{2}$ A maioria dos julgamentos (15) está compreendida no período de 2005 a 2008, mas também foram consultados três julgamentos ocorridos nos anos de 1986 e 1987 (isto é, anteriores à atual Constituição) e outros três julgamentos dos anos de $2000 \mathrm{e}$ 2001 (isto é, posteriores à atual Constituição, mas anteriores ao novo Código Civil).

${ }^{3}$ Autos de Apelação Cível no 259.073.5/5-00, acórdão nº 01203172. Disponível em: http://www.tj.sp.gov.br/consulta/Acordaos.aspx. Consulta em 28/01/2008.

${ }^{4}$ Ver, por exemplo, Hermitte (1998) e Latour (2004a e 2004b).

${ }^{5}$ A respeito da incorporação da tradição do direito romano pelo direito brasileiro, ver Abreu (2008). 
${ }^{6}$ No caso, o artigo 159 do Código Civil de 1916: "Aquele que, por ação ou omissão voluntária, negligência, ou imprudência, violar direito, ou causar prejuízo a outrem, fica obrigado a reparar o dano. A verificação da culpa e a avaliação da responsabilidade regulam-se pelo disposto neste Código, artigos 1.518 a 1.532 e 1.537 a $1.553 "$ ".

${ }^{7}$ Sob este aspecto, é possível sugerir uma aproximação com o contexto, referido por Strathern (2005:117), do debate acerca da norma europeia sobre biotecnologia, em meados da década de 1990. De acordo com a autora, um dos argumentos levantados à época sustentava a possibilidade de patenteamento de partes do corpo humano desde que não fosse mais possível relacioná-las a indivíduos específicos.

${ }^{8}$ Apelação Cível 2007.001.57339. Julgamento realizado pela $13^{a}$ Câmara Cível do Tribunal de Justiça do Rio de Janeiro em 13 de fevereiro de 2008. Disponível em www.tj.rj.gov.br. Consulta em 17/05/2008.

${ }^{9}$ A identificação dos despojos do pai da autora da ação só se tornou possível pela recuperação de um marca-passo, parte não humana do corpo, particularizada por um número de série gravado pelo fabricante.

${ }^{10}$ Também em outro acórdão consultado verifica-se a percepção pelos julgadores de uma conjunção indevida entre humanidade e animalidade, que seria admissível tão-somente no universo da ficção (note-se, de passagem, que alusões à literatura e/ou ao cinema são recorrentes nas manifestações dos julgadores, assim como em textos doutrinários, constituindo uma técnica específica de argumentação). Reproduzo uma breve passagem do voto da desembargadora relatora, acolhido por unanimidade: "O corpo da genitora do autor foi sepultado em um local que mais parece um cemitério de animais, com ossos para todos os lados, mato alto, com uma total falta de higiene, mais parecendo um filme de terror". Apelação Cível no 2006.001.63792. Julgamento realizado pela 13a Câmara Cível do Tribunal de Justiça do Rio de Janeiro em 14 de março de 2007. Disponível em www.tj.rj.gov.br. Consulta em 17/05/2008. Ênfase acrescentada.

${ }^{11}$ A avaliação do dano moral suscita um amplo leque de questões - desde a legitimidade dos requerentes e a natureza das perdas indenizáveis até a adequada expressão pecuniária do dano sofrido - e encaminhamentos distintos conforme o contexto político-jurídico e o caso específico em julgamento. A esse respeito ver, por exemplo, os critérios diferenciados para a indenização de familiares de desaparecidos políticos no Brasil, Argentina e Chile (Mezarobba 2008) e os conflitos que envolveram a indenização a familiares de vítimas dos atentados ao World Trade Center e ao Pentágono em 11 de setembro de 2001, nos Estados Unidos (Zelizer 2005).

${ }^{12}$ Apelação Cível 2008.001.05163. Julgamento pela $6^{\text {a }}$ Câmara Cível do Tribunal de Justiça do Estado do Rio de Janeiro em 2 de abril de 2008. Disponível em www. tj.rj.gov.br. Consulta em 17/05/2008.

${ }^{13}$ Apelação Cível 2007.001.54575. Julgamento pela $16^{\text {a }}$ Câmara Cível do Tribunal de Justiça do Estado do Rio de Janeiro em 11 de março de 2008. Disponível em www.tj.rj.gov.br. Consulta em 19/03/2008. 
${ }^{14}$ A expressão "ex-cônjuge" é utilizada no acórdão para caracterizar o vínculo entre a autora da ação e a pessoa falecida. Não fica claro se a qualificação "ex" faz referência à morte do marido ou se o casal já havia se separado anteriormente.

${ }^{15}$ O Código de Defesa do Consumidor (Lei $\mathrm{n}^{\circ}$ 8.078/90) aplica-se indiferentemente a agentes públicos e privados. Nos acórdãos examinados, porém, parece haver certa relutância dos tribunais em relação ao emprego do CDC quando uma das partes é agente público, optando-se majoritariamente pelo enquadramento legal dos fatos com base na Constituição (artigo 37, § $6^{\circ}$ - "As pessoas jurídicas de direito público e as de direito privado prestadoras de serviços públicos responderão pelos danos que seus agentes, nessa qualidade, causarem a terceiros, assegurado o direito de regresso contra o responsável nos casos de dolo ou culpa") e/ou no Código Civil (artigo 43 "As pessoas jurídicas de direito público interno são civilmente responsáveis por atos dos seus agentes que nessa qualidade causem danos a terceiros, ressalvado direito regressivo contra os causadores do dano, se houver, por parte destes, culpa ou dolo").

${ }^{16}$ O Código de Defesa do Consumidor prevê que a má prestação de um serviço enseja a indenização do consumidor não somente por danos materiais, mas também morais (cf. artigo 6 ${ }^{\circ}$, VI; artigo 14 e artigos 20 a 25). Na doutrina e na jurisprudência, o dano moral tem sido reconhecido como decorrência necessária da frustração das expectativas do consumidor.

${ }^{17}$ Respectivamente, artigos $6^{\circ}$ e 14 do Código do Consumidor. Somente em um dos acórdãos examinados houve a preocupação em se demonstrar a aplicabilidade do CDC aos fatos que deram origem ao processo. Nos demais, considerou-se suficiente declarar o enquadramento do caso como fornecimento defeituoso de um serviço, sem menção explícita à doutrina ou à jurisprudência.

${ }^{18}$ Impedimento ou perturbação de cerimônia funerária (art. 209): pena de detenção de um mês a um ano ou multa; Violação de sepultura (art. 210), e Destruição, subtração ou ocultação de cadáver (art. 211): penas de reclusão de um a três anos e multa; Vilipêndio a cadáver ou suas cinzas (art. 212): pena de detenção de um a três anos e multa. Em termos concretos, a diferença entre reclusão e detenção opera sobretudo como critério para a determinação dos regimes de cumprimento de pena. Se a condenação for de reclusão, a pena pode ser cumprida em regime fechado, semi-aberto ou aberto. Já na detenção não se prevê o regime fechado, salvo em circunstâncias excepcionais.

${ }^{19}$ Não encontrei nenhum processo referente ao impedimento ou perturbação de cerimônia funerária, tipo penal que remonta ao direito romano pré-cristão - a esse respeito, ver a excelente análise de Yan Thomas (2004). Atenho-me, portanto, nas considerações a seguir, aos demais crimes relativos aos mortos definidos pelo Código Penal Brasileiro.

${ }^{20}$ Recurso Crime 70001.799.402. Julgamento da $1^{\text {a }}$ Câmara Criminal do TJRS em 21 de fevereiro de 2001. Revista dos Tribunais 794/674. Consulta eletrônica em 17/05/2008 (www.rt.com.br/JurisOnline). 
${ }^{21}$ Habeas Corpus 16318/2000. Julgamento pela Câmara Especial de Férias do Tribunal de Justiça do Maranhão em 9 de janeiro de 2001. Revista dos Tribunais 790/656. Consulta eletrônica em 17/05/2008 (www.rt.com.br/JurisOnline).

${ }^{22}$ Respectivamente, Apelação 41.767-3, julgada pela $3^{\text {a }}$ Câmara de Direito Penal do Tribunal de Justiça de São Paulo em 10 de março de 1986 (Revista dos Tribunais 608/305, consulta eletrônica em 17/05/2008 - http://www.rt.com.br/JurisOnline), e Apelação 53.500-3, julgada pela $1^{\text {a }}$ Câmara de Direito Penal do Tribunal de Justiça de São Paulo em 18 de maio de 1987 (Revista dos Tribunais 619/291, consulta eletrônica em 17/05/2008 - http://www.rt.com.br/JurisOnline).

${ }^{23}$ A expressão "fabrication by default" caracteriza aquilo que é produzido indiretamente, por implicação, quando o direito evita deliberadamente tratar de (e decidir sobre) determinadas questões particularmente problemáticas. Um exemplo examinado por Strathern é o tratamento conferido a órgãos e tecidos humanos pelo direito britânico. A ênfase no estabelecimento de mecanismos jurídicos de consentimento prévio para a remoção e a posterior destinação desses elementos (que continuam a ser referidos, significativamente, como "partes" do corpo) torna possível deixar de decidir se órgãos e tecidos, uma vez destacados do corpo humano, constituem "coisas" (inteiras) e, desse modo, se estariam sujeitos ao mesmo regime jurídico das demais coisas, notadamente a incorporação ao patrimônio econômico de alguém e a eventual comercialização (Strathern 2005:16-18).

${ }^{24}$ Encontrei apenas um acórdão referente a tais questões. Trata-se do julgamento de recurso apresentado ao Tribunal de Justiça do Rio de Janeiro pelos responsáveis pelo filme Luz del Fuego - biografia romanceada da atriz e dançarina famosa na década de 1950 por se apresentar, em trajes sumários, com o corpo enrolado por uma jiboia. Os autores do recurso pleiteavam a anulação da sentença de primeiro grau que proibiu a exibição do filme, em ação proposta pela irmã da atriz. O julgamento, ocorrido em 1986, é anterior à atual Constituição Federal e ao novo Código Civil. A despeito disso, os julgadores de primeiro e segundo graus respaldam suas decisões na noção de "direitos da personalidade", cujo reconhecimento é entendido, na (então) ausência de "disciplina específica" na legislação brasileira, como um desdobramento necessário da própria "evolução da ciência do direito". Desse modo, a proibição do filme foi mantida a partir do reconhecimento da possibilidade de dano aos direitos da personalidade de um indivíduo morto. Mas, uma vez reconhecidos, esses direitos foram imediatamente convertidos em "direito novo" de terceiros, afetados pelo ato danoso por sua condição de parentes da vítima. Enfim, reconhece-se o dano, mas não a titularidade post mortem dos direitos da personalidade. Apelação 39.193/86 (embargo declaratório). Julgamento pela $3^{a}$ Câmara Cível do Tribunal de Justiça do Rio de Janeiro em 17/12/1985 e 24/06/1986 (Revista dos Tribunais 619/175, consulta eletrônica em 17/05/2008 - http://www.rt.com.br/JurisOnline).

${ }^{25}$ Código Civil - Art. 12. "Pode-se exigir que cesse a ameaça, ou a lesão, a direito da personalidade, e reclamar perdas e danos, sem prejuízo de outras sanções previstas em lei. Parágrafo único. Em se tratando de morto, terá legitimação para requerer a medida prevista neste artigo o cônjuge sobrevivente, ou qualquer parente em linha reta, ou colateral até o quarto grau". 
${ }^{26}$ O surgimento de entidades como a Abrame (Associação Brasileira de Magistrados Espíritas) - que, segundo reportagem do jornal Folha de S. Paulo, congrega cerca de setecentos juízes, desembargadores e ministros de tribunais superiores também contribui para relativizar a fronteira entre vida e morte para o reconhecimento jurídico da manifestação da vontade, uma vez que a materialidade do corpo não é tida como condição necessária para a existência da pessoa e para o exercício de sua capacidade jurídica. A reportagem reproduz trecho de entrevista com o juizauxiliar da presidência do Conselho Nacional de Justiça, Alexandre Azevedo, em que este afirma: "Não enxergaria nenhuma diferença entre uma declaração feita por mim ou por você e uma declaração mediúnica, que foi psicografada por alguém" (Galvão 2008).

${ }^{27}$ A tensão entre esses dois modelos pode ser reconhecida no interior do próprio ordenamento jurídico. A noção de pessoa desenvolvida ao longo do Código Civil prescinde da afirmação de uma correspondência ontológica entre os entes jurídicos e aqueles que existem fora desse universo. Exemplo disso é o reconhecimento de pessoas desprovidas de corpo - as pessoas jurídicas - e, inversamente, a consideração do corpo humano como coisa passível de ser objeto de relações jurídicas, limitandose tão-somente à sua comercialização. Já a Constituição Federal, ao afirmar em seu preâmbulo princípios normativos de legitimidade absoluta, logicamente anteriores e eticamente superiores ao direito formal e à ação estatal, inscreve-se na ampla tendência do constitucionalismo moderno de revitalização da perspectiva jusnaturalista, em oposição ao chamado positivismo jurídico predominante até meados do século XX (ver, a esse respeito, Vianna 1996).

\section{Referências bibliográficas}

ABREU, Luiz E. 2008. “Tradição, direito e política". Comunicação apresentada na $26^{a}$ Reunião Brasileira de Antropologia, GT Antropologia do Estado. Porto Seguro (BA), 01 a 04 de junho de 2008. Mimeo.

AMARAL, Francisco. 2000. Direito Civil: Introdução. Rio de Janeiro: Renovar.

BRASIL . Código Civil Brasileiro. Lei $\mathrm{n}^{\mathrm{o}}$ 10.406, de 10/01/2002.

. Código Civil Brasileiro. Lei no 3.071, de 01/01/1916.

_. Constituição da República Federativa do Brasil, de 05/10/1988.
_ Código de Defesa do Consumidor. Lei no 8.078, de 11/09/1990.

_. Código Penal Brasileiro. Decreto-Lei $\mathrm{n}^{\mathrm{o}} 2.848$, de 07/12/1940.

GALVÃO, Vinícius Queiroz. 2008. "Associação quer espiritualizar o judiciário". Folha de S. Paulo, 19 de maio, p. C1.

GEDIEL, José Antônio Peres. 2000. “Tecnociência, dissociação e patrimonialização jurídica do corpo humano". In: L. Fachin (coord.), Repensando fundamentos do direito civil brasileiro contemporâneo. Rio de Janeiro: Renovar. pp. 57-85. 
HERMITTE, Marie-Angèle. 1998. "Le droit est un autre monde". Enquête, VII:17-37.

LATOUR, Bruno. 2004a. La fabrique du droit: une ethnographie du Conseil d'État. Paris: La Découverte. - 2004b. "Scientific objects and legal objectivity". In: A. Pottage e M. Mundy (eds.), Law, anthropology, and the constitution of the social. Cambridge: Cambridge University Press. pp. 73-114.

MEZAROBBA, Glenda Lorena. 2008. O preço do esquecimento: as reparações pagas às vítimas do regime militar (uma comparação entre Brasil, Argentina e Chile). Tese de doutorado, Universidade de São Paulo.

MUNDY, Martha; POTTAGE, Alain (eds.). 2004. Law, anthropology, and the constitution of the social. Cambridge: Cambridge University Press.

POTTAGE, Alain. 2004. "Introduction: the fabrication of persons and things". In: A. Pottage e M. Mundy (eds.), Law, anthropology, and the constitution of the social. Cambridge: Cambridge University Press. pp. 1-39.

_2007. "The socio-legal implications of the new biotechnologies". Annual Review of Law and Social Science, III:321-344.

STRATHERN, Marilyn. 2005. Kinship, law and the unexpected. Cambridge: Cambridge University Press.

TARTUCE, Flávio. 2005. "Os direitos da personalidade no novo Código Civil". Disponível em http://www.mundojuridico.adv.br. Acesso em 16/05/2008.

THOMAS, Yan. 2004. "Res Religiosae: on the categories of religion and commerce in Roman law". In: A. Pottage e M. Mundy (eds.), Law, anthropology, and the constitution of the social. Cambridge: Cambridge University Press. pp. 40-72.
VIANNA, Luiz Werneck. 1996. "Poder judiciário, 'positivação do direito natural' e política". Estudos Históricos, XVIII:1-20 (www.cpdoc.fgv. $\mathrm{br} /$ revista/arq/195.pdf).

ZELIZER, Viviana. 2005. "Intimité et économie". Terrain [en ligne] 45, mis en ligne le 15 septembre 2009. Disponível em http://terrain.revues. org/index3512.html. Acesso em 15/04/2010. 
Resumo

A partir do exame de decisões de tribunais estaduais brasileiros envolvendo a consideração jurídica do ser humano após a morte, este artigo procura identificar diferentes formas pelas quais as técnicas jurídicas constituem e distinguem pessoas e coisas. A análise dos julgamentos evidencia que a categorização de um ente como pessoa ou coisa depende de distinções contingentes efetuadas no exame de situações particulares, o que implica reconhecer o direito como um poderoso operador ontológico que efetivamente constrói o mundo ao qual suas disposições se referem. Em parte associado à complexa topografia de ramos e especialidades do direito, o caráter contextual da distinção entre pessoas e coisas permite identificar nas decisões judiciais diferentes graus de personificação e reificação, assim como a possibilidade de constituição de pessoas e coisas pela articulação de atributos de entes distintos.

Palavras-chave Direito, Técnicas jurídicas, Mortos, Pessoas e coisas

\section{Abstract}

This paper discusses the fabrication of persons and things through legal techniques, taking as reference a study of Brazilian court rulings involving human beings after death. Analysis of these decisions reveals that any categorization of an entity as a person or thing depends on contingent distinctions made in particular situations, which in turn implies that law is in fact a powerful ontological device creating the world to which it refers. The contextuality of the person/thing distinction, partly associated with the complex topography of legal branches and specialities, allows different degrees of personification and reification to be identified, along with the possibility of fabricating persons and things by combining specific attributes from different entities.

Key words Law, Legal techniques, Dead human beings, Persons and things 